\title{
A record of Holocene environmental and ecological changes from Wildwood Lake, Long Island, New York
}

\section{Citation}

Oswald, W. Wyatt, David R. Foster, Elaine D. Doughty, and Dana Macdonald. 2010. "A Record of Holocene Environmental and Ecological Changes from Wildwood Lake, Long Island, New York." Journal of Quaternary Science 25 (6) (March 1): 967-974. doi:10.1002/jqs.1381.

\section{Published Version}

doi:10.1002/jqs.1381

\section{Permanent link}

http://nrs.harvard.edu/urn-3:HUL.InstRepos:33901523

\section{Terms of Use}

This article was downloaded from Harvard University's DASH repository, and is made available under the terms and conditions applicable to Other Posted Material, as set forth at http:// nrs.harvard.edu/urn-3:HUL.InstRepos:dash.current.terms-of-use\#LAA

\section{Share Your Story}

The Harvard community has made this article openly available.

Please share how this access benefits you. Submit a story.

\section{Accessibility}




\section{A record of Holocene environmental and ecological changes from Wildwood Lake, Long Island, New York}

W. Wyatt Oswald ${ }^{1,2}$, David R. Foster ${ }^{2}$, Elaine D. Doughty ${ }^{2}$, and Dana MacDonald ${ }^{3}$

${ }^{1}$ Emerson College, Boston, MA 02116, USA

${ }^{2}$ Harvard Forest, Harvard University, Petersham, MA 01366, USA

${ }^{3}$ Department of Geological Sciences, Brown University, Providence, RI 02912, USA

Corresponding author:

W. Wyatt Oswald

Emerson College

Boston, MA 02116, USA

Phone: 617-824-3502

Fax: 617-824-8735

Email: w_wyatt_oswald@emerson.edu

For resubmission to Journal of Quaternary Science; December 11, 2009

RUNNING HEAD: Holocene lake-sediment record from Long Island, New York

KEYWORDS: charcoal; fire; paleoecology; pitch pine; pollen 
9 discontinuity may reflect the removal of some sediment during brief periods of reduced water

10 depth at 5300 and $4600 \mathrm{cal}$. a BP. In the upper portion of the record ( $<4500 \mathrm{cal}$. a BP), subtle

11 changes at $\sim 3000$ cal. a BP indicate declining prevalence of Quercus-Fagus-Carya forests and

12 increasing abundance of Pinus rigida, perhaps due to reduced summer precipitation. Elevated

13 percentages of herbaceous taxa in the uppermost sediments represent European agricultural

14 activities. However, unlike charcoal records from southern New England, fire activity does not

15 increase dramatically with European settlement. These findings indicate that present-day Pinus 16 rigida-Quercus ilicifolia woodlands on eastern Long Island are not a legacy of recent, 17 anthropogenic disturbances.

\section{ABSTRACT}

Analyses of pollen, charcoal, and organic content in a lake-sediment core from Wildwood Lake, Long Island, New York, provide insights into the ecological and environmental history of this region. The early-Holocene interval of the record ( 9800-8800 cal. a BP) indicates the presence of Pinus rigida-Quercus ilicifolia woodlands with high fire activity. A layer of sandy sediment dating to $9200 \mathrm{cal}$. a BP may reflect a brief period of reduced water depth, consistent with widespread evidence for cold, dry conditions at that time. Two other sandy layers, bracketed by ${ }^{14} \mathrm{C}$ dates, represent a sedimentary hiatus from $\sim 8800$ to $4500 \mathrm{cal}$. a BP. This

\section{INTRODUCTION}

Numerous paleoecological and paleoenvironmental records provide a broad view of the post-glacial vegetation and climate history of the northeastern United States ("the Northeast"; e.g., Bernabo and Webb, 1977; Gaudreau and Webb, 1985; Williams et al., 2001; Huang et al., 2002; Shuman et al., 2002a; 2002b; 2004; 2005; 2006). Some parts of the region, however, have 
1 received less recent study and thus aspects of their environmental history are not well

2 understood. Long Island, New York, is one area where additional information about past

3 ecological and climatic changes is needed, in particular to improve our understanding of the

4 following: (1) the long-term history of Pinus rigida (pitch pine) woodlands in central and

5 eastern Long Island; (2) the distribution of Fagus grandifolia (American beech) along the

6 Northeast coast during the middle Holocene; and (3) the timing and magnitude of century-scale

7 variations in climate in this region during the Holocene.

8 There are various unresolved questions regarding the origin and history of forests

9 dominated by fire-dependent Pinus rigida and Quercus ilicifolia (scrub oak) on Long Island

10 (e.g., Backman, 1984; Kurczewski and Boyle, 2000; Jordan et al., 2003), which provide habitat

11 for a range of rare and endangered species (CPBJPPC, 1995). It is uncertain whether the Pinus

12 rigida woodlands of eastern Long Island have been maintained for millennia by frequent fire, or

13 if they have expanded more recently in response to European settlement, forest clearance, and

14 burning (e.g., Kurczewski and Boyle, 2000). Pinus rigida communities are threatened by

15 development and fire suppression, and their conservation, management, and restoration should

16 be guided by information about their past (e.g., CPBJPPC, 1995; Jordan et al., 2003; Parshall et 17 al., 2003).

18 Recent paleoecological studies on Cape Cod, Massachusetts, and adjacent islands (Fig. 1)

19 have documented the widespread occurrence of an unusual coastal vegetation type during the

20 middle Holocene (Foster et al., 2006). Beginning with the abrupt collapse of Quercus

21 populations $\sim 5500$ calibrated ${ }^{14} \mathrm{C}$ years before present (cal. a BP), a portion of the coast of

22 southern New England was dominated by Fagus grandifolia. The geographic extent of coastal

23 Fagus forests, which persisted until 3000 cal. a BP, has not been determined for other parts of 
1 the Northeast coast, including Long Island. Several pollen records published some four decades

2 ago (Sirkin, 1967; 1971) suggest that the post-glacial vegetation history of Long Island

3 resembles that of much of southern New England, which can be explained in terms of orbital-

4 scale changes in climate (e.g., Davis, 1969; Suter, 1985; Gaudreau, 1986; Shuman et al., 2001;

5 2004; Oswald et al., 2007). Late-glacial forests featured cold-tolerant Picea (spruce) and Pinus

6 banksiana (jack pine), warmer and drier conditions during the early Holocene resulted in

7 dominance by Pinus strobus (white pine), and wetter conditions after $\sim 8000$ cal. a BP promoted

8 the expansion of various temperate forest taxa, including Quercus. There is no indication of a

9 middle-Holocene interval dominated by Fagus grandifolia on Long Island (Sirkin, 1967; 1971),

10 but the coarse sampling resolution and very limited chronological control restrict the utility of

11 the existing Long Island records.

Recent studies in southeastern Massachusetts, located northeast of Long Island (Fig. 1),

13 show that lake-sediment records from the Northeast feature not only the orbital-scale changes in

14 climate responsible for the broad sequence of vegetation shifts (e.g., Shuman et al., 2001; 2004),

15 but also century-scale intervals of reduced water depth evidenced by sand layers in near-shore

16 cores (e.g., Newby et al., 2009; Shuman et al., 2009). Relatively brief periods of dry conditions

17 associated with changing ocean conditions appear to have occurred at $\sim 9200,8300,5300,4600$,

$183800,2900,2200$, and $1500 \mathrm{cal}$. a BP and may have served as important drivers for some aspects

19 of the vegetation history of the region (Shuman et al., 2004; 2009; Newby et al., 2009).

20 In this paper we discuss a detailed lake-sediment record from Wildwood Lake, located in

21 eastern Long Island (Fig. 1) near the Central Pine Barrens, the largest area of Pinus rigida-

22 Quercus ilicifolia woodlands on Long Island (CPBJPPC, 1995; Jordan et al., 2003). Preliminary

23 data from this record were reported elsewhere (Foster et al., 2006). Our analyses of charcoal, 
1 pollen, and organic content in the Wildwood record provide additional evidence for millennial-

2 to centennial-scale variations in climate and ecosystems in the Northeast (e.g., Newby et al.,

3 2009; Shuman et al., 2009) and contribute to an improved understanding of the origin and

4 dynamics of Pinus rigida forests on Long Island.

6 STUDY AREA

$7 \quad$ Wildwood Lake $\left(40.892^{\circ} \mathrm{N}, 72.673^{\circ} \mathrm{W}\right)$ is a 26 -ha lake located on eastern Long Island,

8 New York; a single outlet to the north flows into the Peconic River. The lake features two basins

9 separated by a shallow shoal: the northern basin is $\sim 3-\mathrm{m}$ in depth; the southern basin is $\sim 15-\mathrm{m}$ in

10 depth at its deepest point, which is near the southernmost lakeshore (Fig. 2). Much of the

11 lakeshore currently is occupied by residential and commercial development. The lake sits on the

12 Ronkonkoma Moraine (e.g., Fuller, 1914; Sirkin, 1971), which is bordered to the north and south

13 by sandy outwash plains (Fig. 1). The dominant soils of the area are Plymouth loamy sand and

14 Carver and Plymouth sands, both of which have relatively low moisture-holding capacity

15 (USDA, 1972; 1975; Kurczewski and Boyle, 2000). Historical maps and witness-tree data

16 (Kurczewski and Boyle, 2000; Cogbill et al., 2002) suggest that outwash plains featured Pinus

17 rigida, Quercus ilicifolia, and some tree oaks (e.g., Q. alba, Q. coccinea, and Q. velutina) at the

18 time of European settlement in the mid-seventeenth century; moraines appear to have been

19 dominated by tree oaks (e.g., Q. rubra, Q. prinus, and Q. velutina), with lesser amounts of Pinus

20 rigida, Castanea dentata (American chestnut), Carya glabra (Pignut hickory), and Fagus

21 grandifolia. The pollen source area (Sugita, 1994) for this relatively large lake likely includes

22 areas of both moraine and outwash. A charcoal record from nearby Deep Pond (Fig. 1) indicates

23 that fires burned periodically during the late Holocene, increasing in frequency and intensity 
1 after European settlement (Backman, 1984). Historical records show that large fires burned

2 across Long Island in the late-eighteenth and nineteenth centuries (Kurczewski and Boyle, 2000).

4 METHODS

5 We recovered a sediment core from Wildwood Lake in July 2001. The core was

6 collected near the center of the southern basin of the lake, 100 m northwest of its deepest point;

7 water depth at the coring location was $14 \mathrm{~m}$ (Fig. 2). Coring ceased at 765-cm sediment depth

8 due to mechanical problems. The uppermost sediments $(165 \mathrm{~cm})$ were obtained with a 7-cm-

9 diameter plastic tube fitted with a piston. Lower sediments were collected in 1-m drive lengths

10 with a 5-cm-diameter modified Livingstone piston sampler. The surface core was extruded

11 vertically in 1-cm intervals; lower cores were extruded horizontally and wrapped in plastic and 12 aluminum foil.

13 Sediment organic content was estimated by measuring percent weight loss-on-ignition

14 (LOI); $1-\mathrm{cm}^{3}$ samples were dried at $90^{\circ} \mathrm{C}$ and ashed at $550^{\circ} \mathrm{C}$ (Bengtsson and Enell, 1986).

15 Macroscopic charcoal content of the sediment was determined by soaking $1-\mathrm{cm}^{3}$ samples in

$16 \mathrm{KOH}$, sieving through a $180-\mu \mathrm{m}$ screen, and counting charcoal pieces $>180-\mu \mathrm{m}$ at $20 \mathrm{X}$

17 magnification (Long et al., 1998). Samples of $1 \mathrm{~cm}^{3}$ from 116 levels were prepared for pollen

18 analysis following standard procedures (Faegri and Iversen, 1989), and tablets containing

19 Lycopodium spores were added to the samples to estimate concentrations and influx (Stockmarr,

20 1971). Pollen residues were analyzed at 400X magnification until a minimum of 500 pollen

21 grains and spores of upland taxa was identified for each level. Pollen percentages are expressed

22 relative to the sum of upland tree, shrub, and herb pollen. Only $\sim 30 \%$ of Pinus pollen grains

23 were identifiable to the subgenus level, but $\sim 90 \%$ of the identified grains were Pinus subgenus 
1 Pinus. We therefore assume that most of the Pinus pollen in the Wildwood record is derived

2 from Pinus rigida.

3 Fossil-pollen assemblages were compared with modern-pollen spectra from eight sites

4 (Figs. 1 and 3) representing the three primary types of upland forest for Long Island and the 5 coastal area of southern New England (Motzkin et al., 2002). Three sites from Cape Cod are

6 dominated by Pinus rigida (Eagle, Fresh, and Round Ponds; Parshall et al., 2003), two Cape Cod

7 sites are dominated by Quercus species (Deep and Sandy Hill Ponds; Parshall et al., 2003), and

8 three sites from Naushon Island are dominated by Fagus grandifolia (Blaney’s Pond, Duck

9 Pond, and Mary’s Lake; W. Oswald and D. Foster, unpublished). Relationships between fossil

10 and modern assemblages were described by the squared-chord distance index of dissimilarity

11 (SCD; Overpeck et al., 1985). Six taxa were included in this analysis: Pinus, Quercus, Fagus,

12 Carya, Betula, and Tsuga. The majority of identified Pinus grains in these modern samples were

13 Pinus subgenus Pinus. Previous studies have shown that SCD values $<0.1$ indicate a strong

14 degree of similarity in the composition of the source vegetation (e.g., Overpeck et al., 1985).

15 Chronological control is provided primarily by accelerator mass spectrometry ${ }^{14} \mathrm{C}$

16 analysis of bulk sediment samples, each spanning $1 \mathrm{~cm}$ core depth (Table 1$).{ }^{14} \mathrm{C}$ dates were

17 converted to calibrated years before present (cal. a BP) with CALIB 5.0 (Reimer et al., 2004).

18 The chronology of the upper sediments is based on ${ }^{210} \mathrm{~Pb}$ analysis (Table 2; Binford, 1990) and

19 pollen stratigraphy: the rise in agricultural taxa at $130 \mathrm{~cm}$ (Fig. 4B, 5A) was assigned an age of

20300 cal. a BP (1650 AD; Kurczewski and Boyle, 2000).

\section{RESULTS}

23 Lithology and chronology 
The Wildwood core is lacustrine sediment (LOI 30\%), with the exception of three sandy

2 layers (LOI <25\%): 650-646 cm, 592-580 cm, and 562-554 cm (Fig. 4A, 4C). Organic content

3 also declines above $130 \mathrm{~cm}$ during the interval of European settlement. The five ${ }^{14} \mathrm{C}$ ages below

$4599 \mathrm{~cm}$ (Table 1) indicate that the lower interval of the record was deposited quickly $(\sim 160 \mathrm{~cm}$

5 in $\sim 1000$ years) and a straight line fit to the median calibrated ${ }^{14} \mathrm{C}$ ages dates the sandy layer at

$6 \sim 650 \mathrm{~cm}$ to $9200 \mathrm{cal}$. a BP (Fig. 4B). A preliminary chronology for this record presented in a

7 regional summary (Foster et al., 2006) assumed that this feature represented the 8200 cal. a BP

8 cold event (e.g., Alley et al., 1997; Alley and Ágústsdóttir, 2005), which appears as an interval of

9 reduced organic content in records from elsewhere in eastern North America (e.g, Spooner et al.,

10 2002; Kurek et al., 2004). However, additional ${ }^{14} \mathrm{C}$ dating and emerging recognition of a

11 climatic event at 9200 cal. a BP at many sites worldwide (e.g., Fleitmann et al., 2008),

12 including southeastern Massachusetts (Newby et al., 2009; J. Hou and Y. Huang, unpublished),

13 support the updated age-depth curve presented here (Fig. 4B). The dates bracketing the sandy

14 layers at $\sim 590$ and $\sim 560 \mathrm{~cm}$ suggest that these features represent a sedimentary hiatus from

$15 \sim 8800$ to $\sim 4500$ cal. a BP. The age model for the upper interval of the core $(\sim 4500$ cal. a BP to

16 the present) involves a straight line fit to the European-settlement horizon and the median

17 calibrated ages of the six ${ }^{14} \mathrm{C}$ dates above $571 \mathrm{~cm}$, and second-order polynomial fit to the

18 European-settlement horizon and the sixteen ${ }^{210} \mathrm{~Pb}$ dates (Tables 1 and 2, Fig. 4B).

20 Pollen and charcoal records

21 The lower interval of the Wildwood core ( 9800-8800 cal. a BP; Fig. 5C) features high

22 percentages of Quercus ( 45\%) and Pinus pollen ( 35\%), with lower percentages of Tsuga

23 (hemlock), Betula (birch), Myrica-Comptonia (bayberry-sweetfern), Poaceae (grass), and 
1 Ambrosia (ragweed). These fossil assemblages are similar to modern spectra from the Quercus-

2 (SCD 0.08) and Pinus-dominated sites (SCD 0.1; Fig 6E) and dissimilar to those from Fagus

3 grandifolia-dominated sites (SCD 0.2). The highest value for Pinus pollen ( $>50 \%$ ) falls within

4 the sandy layer at $\sim 650 \mathrm{~cm}$ that dates to $9200 \mathrm{cal}$. a BP. Charcoal influx values fluctuate

5 between $\sim 40$ and 80 pieces $\mathrm{cm}^{-2} \mathrm{yr}^{-1}$, and Pediastrum influx values vary between $\sim 100$ and 2900

6 algal cell nets $\mathrm{cm}^{-2} \mathrm{yr}^{-1}$ (Fig. 6D).

7 The upper interval of the record ( $4500 \mathrm{cal}$. a BP to the present; Fig. 5B) features 8 gradually increasing Pinus pollen percentages ( 20 to 40\%) and gradually decreasing Quercus

9 values ( 50 to 30\%). Several taxa have higher pollen percentages in the upper interval than in

10 the early-Holocene part of the record, including Betula, Acer (maple), Fagus, Carya, and

11 Castanea. Tsuga pollen-percentage values increase from $\sim 0$ to $5 \%$ between $\sim 4000$ and $2000 \mathrm{cal}$.

12 a BP; Fagus and Carya pollen percentages decrease slightly during that interval. Poaceae and

13 Ambrosia pollen percentages are lower between $\sim 4500$ cal. a BP and European settlement than

14 they were during $~ 9800-8800 \mathrm{cal}$. a BP. The fossil assemblages from $\sim 4500$ to $2000 \mathrm{cal}$. a BP

15 are similar to all three modern-forest types (SCD 0.06-0.1), but the similarity to the Fagus

16 grandifolia-dominated sites declines (SCD 0.1-0.2) and the similarity to modern Pinus samples

17 increases (SCD 0.05) after 2000 cal. a BP (Fig. 6E). Charcoal influx values for the middle

18 and late Holocene are $\sim 5-10$ pieces $\mathrm{cm}^{-2} \mathrm{yr}^{-1}$. Sediment organic content is high between $\sim 4400$

19 and $3000 \mathrm{cal}$. a BP, peaking at $3800 \mathrm{cal}$. a BP, then peaks again at $2000 \mathrm{cal}$. a BP (Fig. 6B).

20 Influx of Pediastrum algal cell nets declines between 4000 and 3000 cal. a BP (Fig. 6D).

21 The changes at $130 \mathrm{~cm}$ (300 cal. a BP) represent the era of European settlement and

22 forest clearance (Fig. 5A). A sharp drop in organic content is presumably attributable to

23 increased erosion of mineral material into the lake (Fig. 6B), and a rise in Pediastrum influx may 
1 indicate changes in the aquatic ecosystem in response to disturbance in the watershed (Fig. 6D;

2 e.g., Jankovska and Komarek, 2000). Rumex (sorrel), Poaceae, and Ambrosia increase

3 dramatically, while Carya, Quercus, and especially Pinus exhibit declining abundances at the

4 beginning of this interval. Decreasing percentages of the herbaceous taxa and increasing Pinus

5 pollen percentages ( $\sim 20$ to $50 \%$ ) in levels dating to $\sim 1950 \mathrm{AD}$ reflect the decline of agricultural

6 activity and reforestation. Charcoal influx values increase from $\sim 5$ to 15 pieces $\mathrm{cm}^{-2} \mathrm{yr}^{-1}$ at $\sim 100$

7 cal. a BP (1850 AD), then reach a peak of $\sim 20-35$ pieces $\mathrm{cm}^{-2} \mathrm{yr}^{-1}$ in levels dating to $\sim 1920-1970$

8 AD (Fig. 5A).

9

10 DISCUSSION

11 The Wildwood Lake record provides new insights into past environmental and ecological

12 changes on Long Island, New York, including century-scale variations in climate and the long-

13 term history of vegetation and fire.

15 Early-Holocene vegetation and fire

16 This sediment core from Wildwood Lake contains only a 1000 year interval of the early

17 Holocene, but nonetheless does contribute to our understanding of Long Island ecosystems

18 between $~ 9800$ and 8800 cal. a BP. The prevalence of Pinus and Quercus, paucity of mesic-

19 forest taxa such as Fagus grandifolia and Carya, relatively high abundance of Ambrosia, and

20 very high charcoal influx values suggest open Pinus-Quercus woodlands with frequent fire on

21 the Ronkonkoma moraine and adjacent areas of outwash. Similar pollen assemblages in early-

22 Holocene samples from other sites on Long Island (Sirkin, 1967; 1971) indicate that this type of

23 vegetation was widespread. High fire activity and open forest structure, as evidenced by 
1 abundant Ambrosia (Faison et al., 2006), are consistent with evidence suggesting that regional

2 climate was relatively dry during this interval (Fig. 6A; Shuman et al., 2001; 2004; 2009; Newby

3 et al., 2009).

4

$5 \quad$ Evidence for century-scale climatic events

6 The decline in organic content that is dated securely to $9200 \mathrm{cal}$. a BP likely represents an

7 interval of particularly dry climate and reduced water levels at Wildwood Lake. A similar

8 feature occurs in the sediments of New Long Pond in southeastern Massachusetts (Newby et al.,

9 2009) and geochemical data from Blood Pond in south-central Massachusetts indicate a $\sim 4^{\circ} \mathrm{C}$

10 temperature decline at that time (J. Hou and Y. Huang, unpublished). Emerging evidence

11 suggests that a widespread climatic event took place at 9200 cal. a BP, presumably caused by a

12 weakening of Atlantic meridional overturning circulation (e.g., Fleitmann et al., 2008). The peak

13 in Pinus pollen abundance at $9200 \mathrm{cal}$. a BP in the Wildwood Lake record may represent a

14 change in vegetation in response to cold, dry conditions. This finding is consistent with other

15 evidence for century-scale ecological changes associated with early-Holocene variations in

16 climate (e.g., Shuman et al., 2004).

17 The organic-content and ${ }^{14} \mathrm{C}$ data demonstrate that the Wildwood core features a $>4000$

18 year hiatus between $\sim 8800$ and $\sim 4500 \mathrm{cal}$. a BP. One interpretation of this finding is that climate

19 was dry and water levels were low throughout this entire period. Webb et al. (1993) offered a

20 similar interpretation based on lake-sediment data from other sites in southern New England.

21 More-recent reconstructions of lake-level changes for sites across the Northeast (e.g., Lavoie and

22 Richard 2000; Newby et al., 2000; Dieffenbacher-Krall and Nurse 2005; Shuman et al. 2005),

23 including Crooked Pond in southeastern Massachusetts (Fig. 6A; Shuman et al., 2001), however, 
1 indicate that the period from $\sim 8000$ to $5500 \mathrm{cal}$. a BP was relatively wet, suggesting that the

2 sedimentary hiatus may not simply represent a continuous interval of dry conditions. Instead, we

3 hypothesize that the pronounced dry events recorded at New Long Pond at 5300 and $4600 \mathrm{cal}$. a

4 BP (Shuman et al., 2009) occurred across the region and also caused major water-level

5 reductions at Wildwood Lake. If the portion of the lake bottom cored for this study were

6 substantially shallower than at present, perhaps by $>10 \mathrm{~m}$, older sediments could have been re-

7 deposited to the deeper part of the lake, resulting in the loss of that interval of the record from

$8 \sim 8800 \mathrm{cal}$. a BP to the time when deeper water levels once again reached this site. The sandy

9 layers at $\sim 590$ and $\sim 560 \mathrm{~cm}$ presumably were re-deposited from the exposed lakeshore and

10 shoal; the ${ }^{14} \mathrm{C}$ dates indicate that those sediments were mixed. Our data suggest that the

11 accumulation of lake sediment resumed $\sim 4500$ cal. a BP, a date consistent with the lake-level

12 reconstructions for Crooked Pond (Shuman et al., 2001) and New Long Pond (Shuman et al., 13 2009).

15 Middle- and late-Holocene vegetation and fire

16 The similarity of middle-Holocene pollen spectra to modern samples from three different 17 types of vegetation (Pinus, Quercus, and Fagus) may be attributable to the large pollen source 18 area of Wildwood Lake. Presumably, the lake receives some pollen from the local vegetation on 19 the Ronkonkoma moraine, as well as some pollen from vegetation on the nearby outwash plains.

20 The similarity of middle-Holocene pollen assemblages to modern Pinus samples suggests that

21 areas of sandy soil were dominated by Pinus rigida, as seems to have been the case during the

22 early Holocene. The forests of the moraine itself, on the other hand, appear to have featured

23 Quercus with some Carya and Fagus grandifolia. The abundance of Fagus, however, is 
1 substantially lower for this interval than in records from Cape Cod and nearby islands, where its

2 pollen percentages reach 30-40\% during 5500-3000 cal. a BP (Foster et al., 2006). Climate

3 appears to have become cooler and wetter between $\sim 4000$ and $2000 \mathrm{cal}$. a BP, as evidenced by

4 rising water levels at Crooked Pond (Shuman et al., 2001), for example. This change may be

5 manifest in the Wildwood Lake record by the declines in Pediastrum influx and organic content

6 at that same time. Several tree taxa exhibit subtle changes in abundance between $\sim 4000$ and

72000 cal. a BP. Most importantly, Quercus, Carya, and Fagus become somewhat less common,

8 whereas Pinus increases in abundance. We interpret this gradual change as a decline in the

9 prevalence of Quercus-dominated hardwood forests and the coincident expansion of some Pinus

10 rigida on the Ronkonkoma moraine. The declining abundance of Fagus in response to cooler,

11 wetter conditions is counterintuitive given its prevalence in northern parts of New England (e.g.,

12 Thompson et al., 1999; Cogbill et al., 2002). Shuman and Donnelly (2006) hypothesize that the

13 seasonality of precipitation may have shifted between the middle and late Holocene, so that even

14 though annual precipitation increased after $\sim 3000 \mathrm{cal}$. a BP, the summer months were drier.

15 Reduced summer rainfall might explain the decline of Fagus and rise of drought-tolerant Pinus

16 rigida in the Wildwood record. Relatively stable charcoal influx values after $\sim 4000$ cal. a BP

17 suggest that fire activity was not altered by these changes in climate and vegetation. This finding

18 contrasts with other fire-history data from eastern North America, which indicate an increase in

19 burning during since 3000 cal. a BP (e.g., Carcaillet and Richard, 2000; Power et al., 2008).

21 Recent changes in fire and Pinus rigida abundance

22 Fire activity, as evidenced by charcoal influx, does not appear to increase at the time of

23 European settlement. This stands in contrast to fire-history data from Deep Pond, located 15 
1 km northwest of Wildwood (Fig. 1; Backman, 1984), and elsewhere in southern New England

2 (Parshall and Foster, 2002), which show a rise in burning. Historical accounts suggest that large

3 fires burned across eastern Long Island in the late-eighteenth and nineteenth centuries (e.g.,

4 Kurczewski and Boyle, 2000), but the Wildwood charcoal record indicates that those fires were

5 typical for the last few millennia. Indeed, they were probably smaller and less intense than fires

6 of the early Holocene; fire activity on Long Island was very high $\sim 9800-8800$ cal. a BP when

7 climate was relatively dry. Historical records suggest that fire frequency and intensity increased

8 when the Long Island Railroad reached eastern Long Island in the mid-nineteenth century

9 (Kurczewski and Boyle, 2000). This change may be reflected in the Wildwood charcoal record

10 by the elevated influx values from 100-0 cal. a BP ( 1850 to 1950 AD).

11 The increase in Pinus and Quercus pollen percentages in the uppermost sediments of

12 Wildwood Lake reflect the establishment of Pinus rigida-Quercus ilicifolia woodlands following

13 the abandonment of agriculture over the last century. Pinus abundance at present appears to be

14 slightly higher than it has been over the last millennium, perhaps indicating that Pinus rigida

15 benefited modestly from the disturbances associate with European settlement, deforestation, and

16 agriculture (Kurczewski and Boyle, 2000). This interpretation is consistent with the ability of

17 Pinus rigida to establish under early-successional conditions (e.g., Motzkin et al., 1996;

18 Windisch, 1999). However, Pinus rigida does not appear to be dramatically more abundant than

19 it was prior to European settlement, suggesting that this vegetation type is not necessarily a

20 legacy of recent anthropogenic disturbances.

21 These analyses of the sedimentary record from Wildwood Lake improve our

22 understanding of Holocene environmental and ecological changes on Long Island, New York,

23 but some questions deserve additional study. Detailed reconstructions of lake-level history (e.g., 
1 Shuman et al., 2001; Newby et al., 2009) for this and other sites are needed to test our

2 hypotheses about past changes in climate and water depth, and the analysis of pollen and

3 charcoal data from other sites on Long Island would provide further insights into past spatial

4 patterns of vegetation and fire.

6 ACKNOWLEDGEMENTS

$7 \quad$ We thank Brian Hall, Tim Parshall, Glenn Motzkin, and Sarah Truebe for field and

8 laboratory assistance. The manuscript was greatly improved by suggestions from Konrad

9 Gajewski, Marilyn Jordan, and two anonymous reviewers. This project was funded by the

10 National Science Foundation, the A. W. Mellon Foundation, the Nature Conservancy, the

11 National Ocean Sciences Accelerator Mass Spectrometry Facility, and a Huret Faculty

12 Development Award.

13

14 


\section{REFERENCES CITED}

Alley RB, Mayewski PA, Sowers T, Stuiver M, Taylor KC, Clark PU. 1997. Holocene climatic instability: a prominent, widespread event 8200 years ago. Geology 25: 483-486.

Alley RB, Ágústsdóttir AM. 2005. The 8k event: cause and consequences of a major Holocene abrupt climate change. Quaternary Science Reviews 24: 1123-1149.

Backman AE. 1984. 1000-year record of fire-vegetation interactions in the northeastern United States: a comparison between coastal and inland regions. M.Sc. thesis, University of Massachusetts, Amherst.

Bengtsson L, Enell M. 1986. Chemical analysis. In Handbook of Holocene Palaeoecology and Palaeohydrology, Berglund BE (ed). John Wiley and Sons: Chichester, UK; 423-454.

Bernabo JC, Webb T, III. 1977. Changing patterns in the Holocene pollen record of northeastern North America: a mapped summary. Quaternary Research 8: 64-96.

Binford MW. 1990. Calculation and uncertainty analysis of ${ }^{210} \mathrm{~Pb}$ dates for PIRLA project cores. Journal of Paleolimnology 3: 253-267.

Carcaillet C, Richard PJH. 2000. Holocene changes in seasonal precipitation highlighted by fire incidence in eastern Canada. Climate Dynamics 16: 549-559.

Central Pine Barrens Joint Planning and Policy Commission (CPBJPPC). 1995. Central Pine Barrens Comprehensive Land Use Plan, Vol. 1-2, http://www.pb.state.ny.us.

Cogbill CV, Burk J, Motzkin J. 2002. The forests of presettlement New England, USA: spatial and compositional patterns based on town proprietor surveys. Journal of Biogeography 29: 1279-1304.

Davis MB. 1969. Climatic changes in southern Connecticut recorded by pollen deposition at Rogers Lake. Ecology 50: 409-422.

Dieffenbacher-Krall AC, Nurse AM. 2005. Late-glacial and Holocene record of lake levels of Mathews Pond and Whitehead Lake, northern Maine, USA. Journal of Paleolimnology 34: 283310.

Faegri K, Iversen J. 1989. Textbook of Pollen Analysis. Fourth edition. John Wiley and Sons, Chichester, UK.

Faison EK, Foster DR, Oswald WW, Doughty ED, Hansen BCS. 2006. Early-Holocene openlands in southern New England. Ecology 87: 2537-2547.

Fleitmann D, Mudelsee M, Burns SJ, Bradley RS, Kramers J, Matter A. 2008. Evidence for a widespread climatic anomaly at around 9.2 ka before present. Paleoceanography 23: PA1102. 
Foster DR, Oswald WW, Faison EK, Doughty ED, Hansen BCS. 2006. A climatic driver for abrupt mid-Holocene vegetation dynamics and the hemlock decline in New England. Ecology 87: 2959-2966.

Fuller ML. 1914. The Geology of Long Island. United States Geological Survey Professional Paper 82, Washington, DC.

Gaudreau DC. 1986. Late-Quaternary vegetational history of the Northeast: paleoecological implications of topographic patterns in pollen distributions. Ph.D. thesis, Yale University, New Haven.

Gaudreau DC, Webb T, III. 1985. Late-Quaternary pollen stratigraphy and isochrone maps for the northeastern United States. In Pollen Records of Late Quaternary North American Sediments, Bryant J, Holloway J (eds). American Association of Stratigraphic Palynologists: Dallas; 247280.

Huang Y, Shuman B, Wang Y, Webb T, III. 2002. Hydrogen isotope ratios of palmitic acid in lacustrine sediments record late-Quaternary climate variations. Geology 30: 1103-1106.

Jankovska V, Komarek J. 2000. Indicative value of Pediastrum and other coccal green algae in palaeoecology. Folia Geobotanica 35: 59-82.

Jordan MJ, Patterson WA, III, Windisch AG. 2003. Conceptual ecological models for the Long Island pitch pine barrens: implications for managing rare plant communities. Forest Ecology and Management 185: 151-168.

Kurek J, Cwynar LC, Spear RW. 2004. The 8200 cal. a BP cooling event in eastern North America and the utility of midge analysis for Holocene temperature reconstructions. Quaternary Science Reviews 23: 627-639.

Kurczewski FE, Boyle HF. 2000. Historical changes in the pine barrens of central Suffolk County, New York. Northeastern Naturalist 7: 95-112.

Lavoie M, Richard PJH. 2000. Postglacial water-level changes of a small lake in southern Quebec, Canada. The Holocene 10: 621-634.

Long CJ, Whitlock C, Bartlein PJ, Millspaugh SH. 1998. A 9000-year fire history from the Oregon Coast Range, based on a high-resolution charcoal study. Canadian Journal of Forest Research 28: 774-787.

Motzkin G, Eberhardt R, Hall B, Foster DR, Harrod JC, MacDonald D. 2002. Vegetation variation across Cape Cod, Massachusetts: environmental and historical determinants. Journal of Biogeography 29: 1439-1454. 
Motzkin G, Foster DR, Allen AE, Harrod JC, Boone RD. 1996. Controlling site to evaluate history: vegetation patterns of a New England sand plain. Ecological Monographs 66: 345-365.

Newby PE, Killoran P, Waldorf M, Shuman B, Webb T, III, Webb RS. 2000. 14,000 years of sediment, vegetation, and water level changes at Makepeace Cedar Swamp, southeastern Massachusetts. Quaternary Research 53: 352-368.

Newby PE, Donnelly JP, Shuman BN, MacDonald D. 2009. Evidence of centennial-scale drought from southeastern Massachusetts during the Pleistocene/Holocene transition. Quaternary Science Reviews 28: 1675-1692.

Oswald WW, Faison EK, Foster DR, Doughty ED, Hall BR, Hansen BCS. 2007. Post-glacial changes in spatial patterns of vegetation across southern New England. Journal of Biogeography 34: 900-913.

Overpeck JT, Webb T, III, Prentice IC. 1985. Quantitative interpretation of fossil pollen spectra: dissimilarity coefficients and the method of modern analogs. Quaternary Research 23: 87-108.

Parshall T, Foster DR. 2002. Fire on the New England landscape: regional and temporal variation, cultural and environmental controls. Journal of Biogeography 29: 1305-1317.

Parshall T, Foster DR, Faison E, MacDonald D, Hansen BCS. 2003. Long-term history of vegetation and fire in pitch pine-oak forests on Cape Cod, Massachusetts. Ecology 84: 736-738.

Power MJ, Marlon J, Ortiz N, Bartlein PJ, Harrison SP, Mayle FE, Ballouche A, Bradshaw RHW, Carcaillet C, Cordova C, Mooney S, Moreno PI, Prentice IC, Thonicke K, Tinner W, Whitlock C, Zhang Y, Zhao Y, Ali AA, Anderson RS, Beer R, Behling H, Briles C, Brown KJ, Brunelle A, Bush M, Camill P, Chu GQ, Clark J, Colombaroli D, Connor S, Daniau A-L, Daniels M, Dodson J, Doughty E, Edwards ME, Finsinger W, Foster D, Frechette J, Gaillard MJ, Gavin DG, Gobet E, Haberle S, Hallett DJ, Higuera P, Hope G, Horn S, Inoue J, Kaltenrieder P, Kennedy L, Kong ZC, Larsen C, Long CJ, Lynch J, Lynch EA, McGlone M, Meeks S, Mensing S, Meyer G, Minckley T, Mohr J, Nelson DM, New J, Newnham R, Noti R, Oswald W, Pierce J, Richard PJH, Rowe C, Sanchez Goñi MF, Shuman BN, Takahara H, Toney J, Turney C, Urrego-Sanchez DH, Umbanhowar C, Vandergoes M, Vanniere B, Vescovi E, Walsh M, Wang X, Williams N, Wilmshurst J, Zhan JH. 2008. Changes in fire regimes since the Last Glacial Maximum: an assessment based on a global synthesis and analysis of charcoal data. Climate Dynamics 30: 887-907.

Reimer PJ, Baillie MGL, Bard E, Bayliss A, Beck JW, Bertrand CJH, Blackwell PG, Buck CE, Burr GS, Cutler KB, Damon PE, Edwards RL, Fairbanks RG, Friedrich M, Guilderson TP, Hogg AG, Hughen KA, Kromer B, McCormac FG, Manning SW, Ramsey CB, Reimer RW, Remmele S, Southon JR, Stuiver M, Talamo S, Taylor FW, van der Plicht J, Weyhenmeyer CE. 2004. IntCal04 Terrestrial radiocarbon age calibration, 26 - 0 ka BP. Radiocarbon 46: 1029-1058. 

level variations and vegetation history at Crooked Pond, southeastern Massachusetts. Quaternary Research 56: 401-410.

Shuman B, Bartlein P, Logar N, Newby P, Webb T, III. 2002a. Parallel climate and vegetation responses to the early Holocene collapse of the Laurentide Ice Sheet. Quaternary Science Reviews 21: 1793-1805.

Shuman B, Webb T, III, Bartlein P, Williams JW. 2002b. The anatomy of a climatic oscillation: vegetation change in eastern North America during the Younger Dryas chronozone. Quaternary Science Reviews 21: 1763-1916.

Shuman B, Newby P, Huang Y, Webb T, III. 2004. Evidence for the close climate control of New England vegetation history. Ecology 85: 1297-1310.

Shuman B, Newby P, Donnelly JP, Tarbox A, Webb T, III. 2005. A record of late-Quaternary moisture-balance change and vegetation response from the White Mountains, New Hampshire. Annals of the Association of American Geographers 95: 237-248.

Shuman B, Donnelly JP. 2006. The influence of seasonal precipitation and temperature regimes on lake levels in the northeastern United States during the Holocene. Quaternary Research 65: 44-56.

Shuman B, Huang Y, Newby P, Wang Y. 2006. Compound-specific isotopic analyses track changes in the seasonality of precipitation regimes in the northeastern United States at ca. 8200 cal. a BP. Quaternary Science Reviews 25: 2992-3002.

Shuman BN, Newby P, Donnelly, JP. 2009. Abrupt climate change as an important agent of ecological change in the Northeast U.S. throughout the past 15,000 years. Quaternary Science Reviews 28: 1693-1709

Sirkin LA. 1967. Late-Pleistocene pollen stratigraphy of western Long Island and eastern Staten Island, New York. In Quaternary Paleoecology, Cushing EJ, Wright HE, Jr. (eds). Yale University Press: New Haven; 248-274.

Sirkin LA. 1971. Surficial glacial deposits and postglacial pollen stratigraphy in central Long Island, New York. Pollen et Spores 13: 93-100.

Spooner I, Douglas MSV, Terrusi L. 2002. Multiproxy evidence of an early Holocene (8.2 kyr) climate oscillation in central Nova Scotia, Canada. Journal of Quaternary Science 17: 639-645.

Stockmarr J. 1971. Tablets with spores used in absolute pollen analysis. Pollen et Spores 13: 615-621.

44

Sugita S. 1994. Pollen representation of vegetation in Quaternary sediments-theory and method 46 in patchy vegetation. Journal of Ecology 82: 881-897. 
Suter SM. 1985. Late-glacial and Holocene vegetation history in southeastern Massachusetts: a 14,000-year pollen record. Current Research in the Pleistocene 2: 87-89.

Thompson RS, Anderson KH, Bartlein PJ. 1999. Atlas of relations between climatic parameters and distributions of important trees and shrubs in North America. U. S. Geological Survey Professional Paper 1650, http://pubs.usgs.gov/pp/p1650-a.

United States Department of Agriculture (USDA). 1972. General Soil Map, Suffolk County, New York.

United States Department of Agriculture (USDA). 1975. Soil Survey of Suffolk County, New York.

Webb RS, Anderson KA, Webb T, III. 1993. Pollen response-surface estimates of LateQuaternary changes in the moisture balance of the northeastern United States. Quaternary Research 40: 213-227.

Williams JW, Shuman BN, Webb T, III. 2001. Dissimilarity analyses of late-Quaternary vegetation and climate in eastern North America. Ecology 82: 3346-3362.

Windisch AG. 1999. Fire Ecology of the New Jersey Pine Plains and Vicinity. Ph.D. thesis, Rutgers University, New Brunswick. 
Table 1: ${ }^{14} \mathrm{C}$ results for the Wildwood Lake sediment core

\begin{tabular}{|r|l|l|l|r|r|}
\hline Depth $(\mathrm{cm})$ & ${ }^{14} \mathrm{C}$ lab code & $\delta^{13} \mathrm{C}$ & ${ }^{14} \mathrm{C}$ date & Cal age range $(2 \sigma)$ & Median cal age \\
\hline 207 & AA-58100 & -27.98 & $1300 \pm 40$ & $1143-1301$ & 1237 \\
\hline 264 & AA-58101 & -27.70 & $1240 \pm 40$ & $1068-1270$ & 1179 \\
\hline 417 & OS-47543 & -25.48 & $3080 \pm 40$ & $3171-3383$ & 3301 \\
\hline 549 & OS-72387 & -25.43 & $4510 \pm 40$ & $5039-5310$ & 5163 \\
\hline 569 & OS-72388 & -26.14 & $4030 \pm 40$ & $4417-4784$ & 4497 \\
\hline 571 & OS-56478 & -25.80 & $3860 \pm 35$ & $4156-4412$ & 4290 \\
\hline 599 & OS-72389 & -23.81 & $7980 \pm 60$ & $8645-9004$ & 8844 \\
\hline 617 & OS-47544 & -24.49 & $8070 \pm 60$ & $8720-9240$ & 8987 \\
\hline 654 & OS-56479 & -25.25 & $8210 \pm 45$ & $9021-9302$ & 9175 \\
\hline 697 & OS-56480 & -24.87 & $8440 \pm 40$ & $9333-9531$ & 9474 \\
\hline 762 & OS-47545 & -24.28 & $8790 \pm 60$ & $9563-10,151$ & 9822 \\
\hline
\end{tabular}

Table 2: ${ }^{210} \mathrm{~Pb}$ results for the Wildwood Lake sediment core

\begin{tabular}{|r|r|}
\hline Depth (cm) & Age (relative to AD 1950) \pm S.D. \\
\hline 0 & $-50.0 \pm 0.6$ \\
\hline 4 & $-46.9 \pm 0.6$ \\
\hline 8 & $-42.6 \pm 0.6$ \\
\hline 12 & $-38.4 \pm 0.6$ \\
\hline 16 & $-33.5 \pm 0.6$ \\
\hline 20 & $-29.3 \pm 0.6$ \\
\hline 24 & $-24.5 \pm 0.6$ \\
\hline 28 & $-18.8 \pm 0.6$ \\
\hline 32 & $-10.5 \pm 0.6$ \\
\hline 36 & $3.4 \pm 0.7$ \\
\hline 40 & $11.0 \pm 0.7$ \\
\hline 44 & $18.5 \pm 0.8$ \\
\hline 48 & $26.2 \pm 0.9$ \\
\hline 52 & $33.9 \pm 1.0$ \\
\hline 56 & $41.7 \pm 1.2$ \\
\hline 64 & $66.5 \pm 2.2$ \\
\hline 72 & $95.5 \pm 10.6$ \\
\hline
\end{tabular}




\section{FIGURE CAPTIONS}

Figure 1: Map of Long Island, New York and Cape Cod, Massachusetts featuring surficial geology and showing location of Wildwood Lake, other fossil-pollen sites on Long Island (Sirkin, 1967; 1971; Backman, 1984), Cape Cod sites used for modern-analogue analysis (Parshall et al., 2003; W. Oswald and D. Foster, unpublished), and Crooked and New Long Ponds in southeastern Massachusetts (Shuman et al., 2001; 2009; Newby et al., 2009).

Figure 2: Aerial photo and bathymetric map of Wildwood Lake. Contour interval is 3 m; black circle indicates coring location.

Figure 3: Modern-pollen data from sites in southeastern New England: Eagle Pond, Fresh Pond, Round Pond, Deep Pond, Sandy Hill Pond (Parshall et al., 2003), Blaney’s Pond, Duck Pond, and Mary’s Lake (W. Oswald and D. Foster, unpublished).

Figure 4: (A) Lithology of the Wildwood Lake sediment core; gray shading indicates lacustrine

sediment; black shading indicates sandy layers. (B) Age-depth model; open circles are ${ }^{210} \mathrm{~Pb}$ dates, triangle is European settlement; squares are calibrated ${ }^{14} \mathrm{C}$ dates. (C) Organic content estimated by percent weight loss-on-ignition.

Figure 5: Pollen percentages diagram for selected taxa and charcoal influx values. Separate diagrams are shown for: (A) 1000 cal. a BP to present; (B) 4500 cal. a BP to present; (C) 9800-8800 cal. a BP. Dashed charcoal-influx lines in (A) and (B) represent 2X exaggeration. Estimated age for European settlement is 300 cal. a BP.

Figure 6: (A) Lake-level reconstructions for sites in southeastern Massachusetts; water-depth estimates for Crooked Pond (Shuman et al., 2001); triangles are dry events evidenced by sand layers in sediments of New Long Pond (Newby et al., 2009; Shuman et al., 2009). (B) Wildwood Lake organic content, estimated by percent weight loss-on-ignition. (C) Influx of macroscopic charcoal for Wildwood Lake. (D) Influx of Pediastrum algal cell nets in the Wildwood record. (E) Mean squared chord distance (SCD) values for comparison of Wildwood 
Lake fossil pollen assemblages with modern pollen spectra from sites dominated by Fagus ( $\mathrm{n}=3$;

W. Oswald and D. Foster, unpublished), Quercus ( $\mathrm{n}=2$; Parshall et al., 2003), and Pinus ( $\mathrm{n}=3$;

Parshall et al., 2003). SCD values $<0.1$ indicate similar vegetation composition. 